\title{
"The impact of e-marketing orientation, technological orientation and learning capacity on online SME performance"
}

\begin{tabular}{|c|c|}
\hline AUTHORS & $\begin{array}{l}\text { Ahmed Al Asheq (i) } \\
\text { R } \\
\text { Khadiza Rahman Tanchi (D) } \\
\text { Md. Kamruzzaman (D) } \\
\text { Md. Mobarak Karim (D) }\end{array}$ \\
\hline ARTICLE INFO & $\begin{array}{l}\text { Ahmed Al Asheq, Khadiza Rahman Tanchi, Md. Kamruzzaman and Md. Mobarak } \\
\text { Karim (2021). The impact of e-marketing orientation, technological orientation } \\
\text { and learning capacity on online SME performance. Innovative Marketing , 17(3), } \\
\text { 168-179. doi:10.21511/im.17(3).2021.14 }\end{array}$ \\
\hline DOI & http://dx.doi.org/10.21511/im.17(3).2021.14 \\
\hline RELEASED ON & Monday, 27 September 2021 \\
\hline RECEIVED ON & Saturday, 14 August 2021 \\
\hline ACCEPTED ON & Wednesday, 22 September 2021 \\
\hline LICENSE & $\begin{array}{l}(c)) E Y \\
\text { This work is licensed under a Creative Commons Attribution } 4.0 \text { International } \\
\text { License }\end{array}$ \\
\hline JOURNAL & "Innovative Marketing " \\
\hline ISSN PRINT & $1814-2427$ \\
\hline ISSN ONLINE & $1816-6326$ \\
\hline PUBLISHER & LLC "Consulting Publishing Company "Business Perspectives" \\
\hline FOUNDER & LLC "Consulting Publishing Company "Business Perspectives" \\
\hline
\end{tabular}

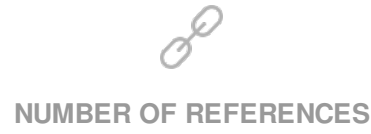

45

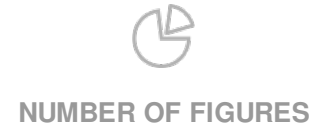

2
NUMBER OF TABLES

4

(C) The author(s) 2021. This publication is an open access article. 


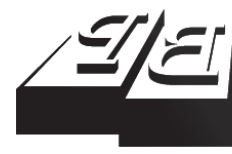

\section{BUSINESS PERSPECTIVES}

LLC "CPC "Business Perspectives" Hryhorii Skovoroda lane, 10, Sumy, 40022, Ukraine www.businessperspectives.org

Received on: $14^{\text {th }}$ of August, 2021 Accepted on: 22nd of September, 2021 Published on: $27^{\text {th }}$ of September, 2021

(C) Ahmed Al Asheq, Khadiza Rahman Tanchi, Md. Kamruzzaman, Md. Mobarak Karim, 2021

Ahmed Al Asheq, Lecturer World School of Business, World University of Bangladesh, Bangladesh (Corresponding author).

Khadiza Rahman Tanchi, Associate Professor (PhD), Business Administration Department, Daffodil International University, Bangladesh.

Md. Kamruzzaman, Assistant Professor, Business Administration Department, Daffodil International University, Bangladesh.

Md. Mobarak Karim, Senior Lecturer World School of Business, World University of Bangladesh, Bangladesh.

This is an Open Access article, distributed under the terms of the Creative Commons Attribution 4.0 International license, which permits unrestricted re-use, distribution, and reproduction in any medium, provided the original work is properly cited.

Conflict of interest statement: Author(s) reported no conflict of interest
Ahmed Al Asheq (Bangladesh), Khadiza Rahman Tanchi (Bangladesh), Md. Kamruzzaman (Bangladesh), Md. Mobarak Karim (Bangladesh)

\section{THE IMPACT OF E-MARKETING ORIENTATION, TECHNOLOGICAL ORIENTATION AND LEARNING CAPACITY ON ONLINE SME PERFORMANCE}

\begin{abstract}
Currently, Internet penetration is accelerating across the country in Bangladesh, which, in particular, has led to the simultaneous development and growth of online businesses. Due to increased internet availability and accessibility, a number of small and medium enterprises (SMEs) continue to operate using an Internet-driven online platform. This context requires a research effort to investigate the underlying factors that might influence the business performance of online SMEs. Thus, the aim of the study is to examine the impact of e-marketing orientation (EMO), technology orientation (TO), and learning capability (LC) on online SME performance in the context of Bangladesh. In this study, the dependent variable is online SME performance, whereas the independent variables are EMO, TO and LC. To achieve this objective, the study developed a questionnaire based on past literature. Following a non-probability random sampling approach, 320 survey forms were distributed among online SME owners using the online survey system (Google form), and finally 156 responses were realized as fully complete responses. Hence, the study sample size is $n=156$. SPSS version no. 26 was used to analyze the correlation among independent and dependent variables and to test the hypotheses. During statistical analysis, the 5\% significance level is used as a threshold value to accept hypotheses. The study results show that EMO, TO and LC have a statistical and significant impact on online SME performance. Finally, this paper seeks to outline several important implications for online SME owners, as well as suggest several directions for future research.
\end{abstract}

Keywords

e-marketing, technology, learning capability, SME performance, Bangladesh

JEL Classification M10, M13, M31

\section{INTRODUCTION}

Recently, the concept of e-marketing has gained considerable interest among academics, researchers, and management practitioners across the globe and has become a new paradigm in the field of marketing research (Eid \& El-Gohary, 2013). Research suggests that Small and Medium-sized Enterprises (SMEs) are likely to obtain an array of business benefits such as increased profits, reduced costs and convenient services for business clients through the adoption of e-marketing (Ainin et al., 2015). Although within the strategic orientation, the influence of both entrepreneurial and market orientation on SME performance have remained the core center of research in the findings of prior studies (Buli, 2017; Laukkanen et al., 2013; Keh et al., 2007), still, the relationship between e-marketing orientation (EMO) and online SME performance is rarely investigated in the past research studies, especially in the developing economies such as Bangladesh. Again, technology orientation (TO), as a feature of competitive advantage, has also remained a focus of researchers' attention, as technol- 
ogy-oriented business firms are likely to provide sophisticated and new technology embedded goods and services to meet customer needs (Gao et al. 2007). Meanwhile, in today's digital business ecosystem, learning capabilities (LC) also offer a source of competitiveness for business organizations in the long run (Real et al., 2014). Hence, it is equally important for business firms to place a strategic emphasis on developing learning capability to sustain in today's digitalized business world.

Simultaneously, Small and Medium-sized Enterprises (SMEs) have undoubtedly been regarded as a potential contributor to a country's overall economic development (Yousaf \& Majid, 2016). For Bangladesh, SMEs have played a salient role in accelerating the economic growth over the years, and approximately 50 percent of Bangladesh's industrial output comes from around 6 million SMEs (Raihan et al., 2016). However, the recent advancement in the Information Technology (IT) sector has gradually transformed the landscape of traditional businesses, even this is also applicable for SMEs too. But little research has been done to determine the effect of e-marketing, learning capability and technology orientation on the online SME performance in developing countries. Since the online SMEs are increasingly growing in Bangladesh, it has become a research urgency to investigate the determinants of the performance of SMEs in Bangladesh. Thus, this study attempts to examine the impact of e-marketing (EMO), technology orientation (TO) and learning capability (LC) on online SME performance in Bangladesh.

Specifically, this study seeks to answer the following research question:

(1) Is online SME firm performance impacted by e-marketing orientation (EMO), technology orientation (TO), and learning capability (LC)?

This study yields several notable contributions to the existing literature. First, it exhibits a statistical test of existing assumptions associated with the impact of e-marketing, technology orientation and learning capability on online SME performance, especially in the context of developing economies. Secondly, it considers two variables, EMO and LC, which are scarcely researched in the literature, as well as seeks to examine the influence of EMO and LC on online SMEs in the context of Bangladesh. Online-based SMEs are still developing in Bangladesh; at the same time, the spread and usage of Internet is also increasing day by day. Most SMEs now have their own website or Facebook page. Accordingly, there has been a huge opportunity for SMEs to leverage the Internet to enhance their business performance. According to this study, SME owners/entrepreneurs can upgrade their business growth by adopting and practising e-marketing, learning capability and technological tools.

This study is organized in the following way. First, a literature review is presented followed by hypotheses development. The following sections provide methodology, results and discussion. The last section includes a conclusion with implications and directions for future research.

\section{LITERATURE REVIEW}

This section seeks to incorporate relevant literature on developing the relationship between e-marketing orientation (EMO), technology orientation (TO), and learning capability (LC) with online SME performance in Bangladesh.

In developing countries such as Bangladesh, online business development is still in its infancy. Information technology plays a crucial role in effectively supporting and accelerating the operation- al activities of a business organization (Brodie et al., 2007). Importantly, information technology is proven to be a facilitator to ensure the sustainability of small business firms (Chatterjee et al., 2020). The Internet-driven online technology has been regarded as a vital platform for small and medium business firms for further development (Mandal, 2017). Based on this premise, the study has focused on the factors that could have a significant impact on online SME performance. To determine online SME performance, the study considers three variables, namely e-marketing orientation (EMO), tech- 
nology orientation (TO), and learning capability (LC), and analyzes their impacts on online performance of SME business firms.

E-marketing Orientation (EMO): Recently, the core attention of academic scholars has already shifted to the application of the e-marketing concept (Tsiotsou \& Vlachopoulou, 2011). The popularity and recognition of e-marketing is expanding, and its crucial role has been affecting the firms' success among the diversified sectors within the business environment. Electronic marketing reflects the implementation of information and communication-oriented technologies to purposefully attain marketing objectives (Shaltoni et al., 2018). Coviello et al. (2001) described e-marketing as "using the Internet and other interactive technologies to create and mediate dialogue between the firm and identified customers" (p. 26). Basically, it is a supplement of the internet based online/digital marketing activities. Adoption of e-marketing activities is about to bring cost minimization and facilitate improvement in reaching many customers. Watson et al. (2002) stated that the expenses of adopting e-marketing are comparatively cheaper than that of other marketing activities (i.e. doorto-door sales or distribution). E-marketing is likely to play a pivotal role in creating a paradigm shift in today's business and also in the consumer behaviors (Sheth \& Sharma, 2005). E-marketing Orientation (EMO) has become an organizational strategic precondition that needs to be aligned with all activities of a business firm to fulfill customer needs (Shaltoni \& West, 2010). The EMO literatures is still limited by a scarce empirical research done to examine the effect of EMO on online firm performance. Hooper et al. (2007) show that the integration of both information technology and marketing is likely to have a positive influence on a firm's business performance. Borges et al. (2009) have revealed that marketing activities, followed by the alignment of internet, may indirectly impact firm performance via market orientation. Empirical studies indicate that the integration of the internet helps to facilitate transaction-oriented business activities, namely, order placement, sale of the products, payment settlement, which are strongly related to the increased and enhanced firm performance (Drennan \& McColl-Kennedy, 2003). Ariyachandra and Frolick (2008) found that e-marketing activities have been found to af- fect SME performance. Mutlu and Sürer (2016) also found a positive impact of e-marketing orientation on the overall performance of health organizations in Turkey.

Technology Orientation (TO): In the era of globalization, the technological orientation has drastically changed and shifted the paradigm of the on-going business sector (Saqib et al., 2018). The new technological development has brought about incredible changes in organizations conduct their business. Technological orientation is considered as a critical determinant of innovation or strategic mechanism that helps to create innovative ideas for business firms (Idrus et al., 2020). Technological innovation is the key issue in modern business sectors that helps to exchange information, share knowledge, expand communication from one place to another in a swift moment, improve cooperation, and disseminate and exchange knowledge through using technological tools in the business activities (García-Sánchez et al., 2018). This technological orientation is highly essential for updating new technology to meet up the challenges pertaining to business or organizational performance, and through utilizing technological facilities, business organizations can become more attentive regarding scientific enlargements (Yousaf et al., 2020). Technological orientation is such a technical skill for business sectors that would potentially help to ensure maximum return based on providing better products and services in the business market. In this concern, the technology business applications help business organizations produce quality products and services as per requirements of customers in the market (Kocak et al., 2017). Technology orientation (TO) also enhances the operation capacity of business firms to offer better customer value (Ozkaya et al., 2015). Several studies have found a positive connection between technology orientation and various aspects of business performance across different business sectors (Ardito \& Dangelico, 2018; Hao \& Song, 2016).

Learning Capability (LC): The notion of "Learning Capability" is defined as "the organizational and managerial characteristics that facilitate organizational learning process or allow an organization to learn" (Chiva et al., 2007, p. 225). Learning capability has been indispensible to gather and disseminate knowledge, and to apply knowledge to 


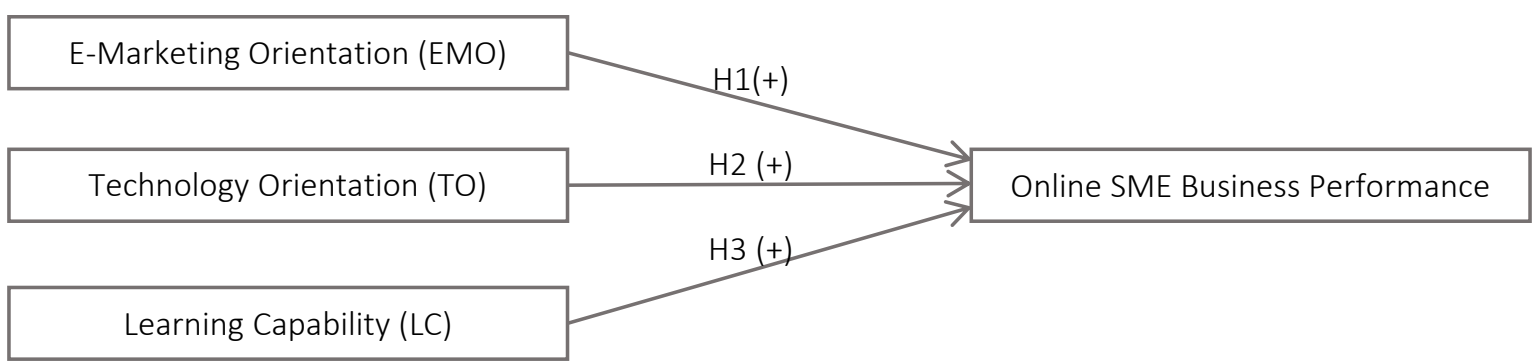

Figure 1. Research model of the study

reinforce the facilitation and transformation of a firm's business capabilities (Zollo \& Winter, 2002). The pursuit of learning helps business organizations to identify new production avenues for their business development (Ambrosini \& Bowman, 2009). It helps business organizations to adapt to the uncertain and turbulent business environment (Alegre \& Chiva, 2008). Learning capability promotes knowledge acquisition and diffusion process across various departments within a business organization, which would lead to creating new product or service (Mallén et al., 2016). A recent study reports that learning capability directly affects the business performance of Indonesian ICT SMEs (Siahaan \& Tan, 2020).

\section{Objectives and hypotheses development}

The objective of this paper is to examine whether the three independent variables - EMO, TO and LC - affect the performance of online SMEs, as there has been very little research done to examine online SME performance, especially in the Bangladesh perspective. Based on previous research, the following hypotheses are advanced:

H1: E-marketing orientation (EMO) has a significant impact on online SME performance.

H2: Technology orientation (TO) has a significant impact on online SME performance.

H3: Learning capability (LC) has a significant impact on online SME performance.

\section{Research model of the study}

Based on the literature review and development of hypotheses, the study proposes the research model (see Figure 1).

\section{METHODOLOGY}

The study intends to explore the impact of e-marketing orientation (EMO), technology orientation (TO) and learning capability (LC) on online SME performance in Bangladesh. To achieve this research objective, the study purposely considered those SME business firms that exercised their business functions online using social media websites. The study applied a non-probability random sampling method as the exact number of current online SMEs operating in Bangladesh was not known during data collection phase. Based on past research, the study developed an online survey questionnaire, and via a Google form, the questionnaire was sent to 320 online SME Bangladeshi business owners by email. In the survey questionnaire, the study objective, along with the clarification on definitions of e-marketing orientation, technology orientation and learning capability, was explicitly incorporated so that respondents could easily understand the essence of the study. In return, 166 responses were received, while out of 166 responses, 10 were removed due to incompleteness. Hence, the final sample size of the study was $n=156$.

The study has developed the survey questionnaire based on previously tested constructs. To assess the reliability of the constructs, the Cronbach Alpha (a) value of at least 0.70 or more than 0.70 was considered as the acceptable value. The construct of e-marketing orientation (EMO) was adopted from Yousaf et al. (2018) and examined by four items. The construct of EMO was found reliable $(\alpha=0.823)$. Technology orientation (TO) was adopted from Lee et al. (2015) and examined by four items. The reliability score of this construct: TO was found acceptable $(\alpha=0.774)$. Learning capability (LC) was adopted from HernándezLinares et al. (2021) and assessed by five items. 
This variable was found reliable as the value of $\alpha$ is 0.842 . The online SME performance was adopted from Lee et al. (2015) and examined by three items. All items under each construct were measured by a five-point Likert scale, where ' 5 ' refers to 'highly satisfied', ' 3 ' means 'neutral', and ' 1 ' refers to 'highly dissatisfied'. The questionnaire consisted of two sections, where the first section asked about respondents' basic information such as their current age, sex, years of operating business on the online platform, etc. In the second section of the questionnaire, a Likert-based questionnaire was asked for the study variables. For data analysis, SPSS software was used to extract demographic information, and regression analysis was performed to test hypotheses.

\section{RESULTS}

\subsection{Demographic statistics of respondents}

Bangladeshi online SME owners were the respondents in this study $(n=156)$. Of the 320 online survey questionnaires distributed, 156 responses were considered complete, and from that point on, the study considered 156 to be the final sample size. Table 1 shows the basic demographic information about online SME owners.

Table 1 shows that $82 \%$ of the sample respondents were male and $18 \%$ were female respondents. In context of age distribution, $33 \%$ of the respondents were between 18 and 30 years old, $41 \%$ were between 31 and 40 , and $18 \%$ of the respondents were 41 to 50 years (see Table 1). Only 13 respondents were over 50 years old (8\%). With regard to marital status, about $68 \%$ of the respondents was single and $32 \%$ were married out of 156 respondents. As per the length of continuing online business operation, $81 \%$ of SME owners' length of operating their online business has fallen in between ' 0 to 3' years, $14 \%$ of SME owners' length of operating business has fallen in between 3-6 years, and 5\% online SME owners have been continuing their online business for more than 6 years. With regard to educational background, about $55 \%$ of respondents have a master's degree and $26 \%$ of respondents have a bachelor degree. Only $12 \%$ of respondents have completed their study to the HSC (Higher Secondary School Certificate) level, and 8\% respondents received only a diploma degree. There were no respondents in this study who actually had a doctoral degree (see Table 1).

Table 1. Demographic information about online SME owners

\begin{tabular}{|c|c|c|}
\hline Demographic information & Frequency & Percentage (\%) \\
\hline \multicolumn{3}{|l|}{ Age } \\
\hline 18 to 30 years & 51 & 32.7 \\
\hline 31 to 40 years & 64 & 41.1 \\
\hline 41 to 50 years & 28 & 17.9 \\
\hline More than 50 years & 13 & 8.3 \\
\hline \multicolumn{3}{|l|}{ Gender } \\
\hline Male & 128 & 82.1 \\
\hline Female & 28 & 17.9 \\
\hline \multicolumn{3}{|l|}{ Marital Status } \\
\hline Single & 106 & 67.9 \\
\hline Married & 50 & 32.1 \\
\hline \multicolumn{3}{|l|}{ Length of Continuing Online Business Operation } \\
\hline 0 to 3 years & 127 & 81.4 \\
\hline 3 to 6 years & 22 & 14.1 \\
\hline More than 6 years & 7 & 4.5 \\
\hline \multicolumn{3}{|l|}{ Education } \\
\hline Doctorate Degree & 0 & 0.0 \\
\hline Master Degree & 85 & 54.5 \\
\hline Bachelor Degree & 40 & 25.6 \\
\hline Higher Secondary School Certificate & 19 & 12.2 \\
\hline Diploma & 12 & 7.7 \\
\hline
\end{tabular}

Note: ${ }^{* *} n=156$. 
Table 2. Correlation analysis

\begin{tabular}{|c|c|c|c|c|c|c|}
\hline & Variables & Mean & OSP & EMO & TO & LC \\
\hline 1 & Online SME Performance (OSP) & 3.8047 & 1 & - & - & - \\
\hline 2 & E-Marketing Orientation (EMO) & 4.1278 & $0.411^{* *}$ & 1 & - & - \\
\hline 3 & Technology Orientation (TO) & 3.9883 & $0.350^{* *}$ & $0.704^{* *}$ & 1 & - \\
\hline 4 & Learning Capacity (LC) & 3.8820 & $0.383^{* *}$ & $0.467^{* *}$ & $0.463^{* *}$ & 1 \\
\hline
\end{tabular}

Note: $* *$ Correlation is significant at the 0.01 level (2-tailed); $n=156$.

Table 3. Regression analysis

\begin{tabular}{l|c|c|c|c|c}
\hline \multicolumn{1}{c|}{ Independent variables } & $\boldsymbol{\beta}$ value & $\boldsymbol{t}$-value & $\boldsymbol{S}$ Sig. & Tolerance & VIF \\
\hline E-Marketing Orientation (EMO) & 0.260 & 3.033 & $0.003^{* *}$ & 0.479 & 2.087 \\
\hdashline Technology Orientation (TO) & 0.279 & 3.693 & $0.000^{* * *}$ & 0.481 & 2.077 \\
\hline Learning Capacity (LC) & 0.235 & 3.422 & $0.001^{* *}$ & 0.747 & 1.340 \\
\hline
\end{tabular}

Note: $R^{2}=0.317$ or $31.7 \%$. Durbin Watson value $=1.592$. Dependent variable: Employee Performance $(\mathrm{EP}) .{ }^{* *} p<0.05$; $* * * p<0.01(n=156)$.

\subsection{Correlation analysis}

Table 2 shows the correlation analysis between the dependent variable (online SME performance) and independent variables (e-marketing orientation, technology orientation, learning capacity). Table 2 clearly indicates that all three independent variables were significantly and statistically correlated with online SME performance at the $1 \%$ significance level. It is observed that e-marketing orientation (EMO) has been powerfully correlated with online SME performance ( $r=0.411)$, technology orientation (TO) is strongly correlated with online SME performance $(r=0.350)$, and finally, learning capacity (LC) is robustly correlated with online SME performance $(r=0.383)$. The correlation results also show that EMO is more strongly correlated with online SME performance than the other two independent variables in the study.

\subsection{Hypotheses testing and regression analysis}

Table 3 shows that the value of the Durbin-Watson test in this study is 1.592, which is considered as an acceptable value as it does fall in the recommended value range from 1.5 to 2.5 (Durbin \& Watson, 1950). In this study, the values of VIF (variance inflation factor) are found to fall under the threshold value of 5.00, and also tolerance values are fallen within the admissible range of 0.1 to 1.0 (Kutner et al., 2004), which essentially unveils that no multi-collinearity problems were reported in the research model. Table 3 and Figure 2 also show the result analysis of the regression coefficient results. The $R^{2}$ value of 0.317 indicates the research model explains 31.7 percent variance, which implies that three independent variables: e-marketing orientation (EMO), technology orientation (TO) and

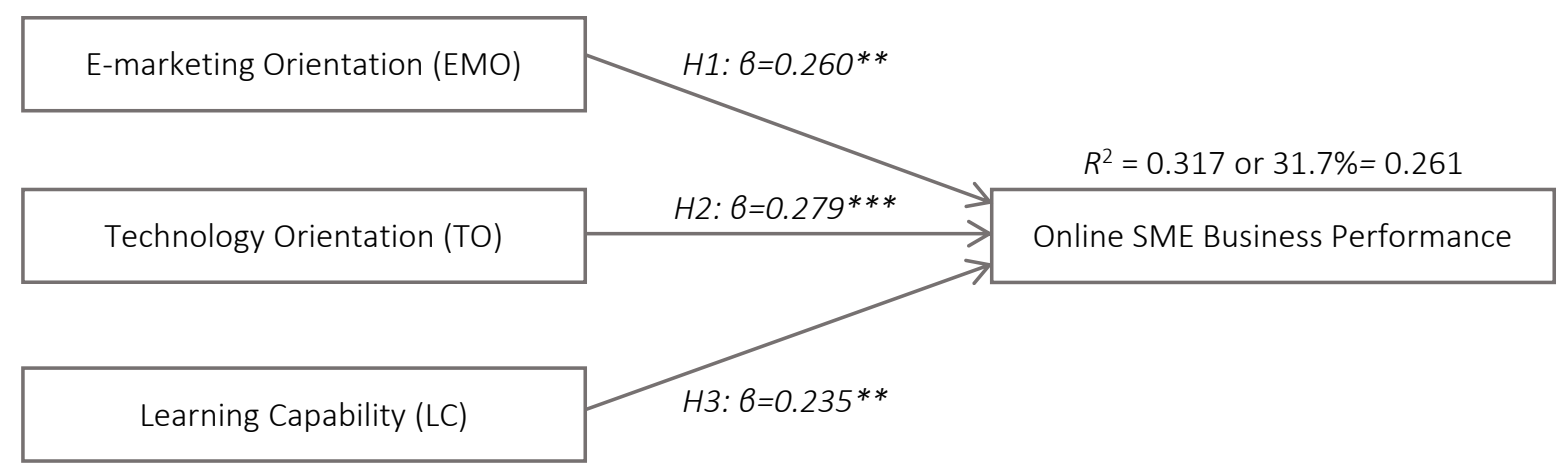

Figure 2. Result analysis of regression coefficient 
Table 4. Summary of hypothesis testing

\begin{tabular}{ccc}
\hline Proposed Hypotheses & Decision \\
\hline H1: E-marketing orientation has a significant impact on online SME performance & Accepted \\
H2: Technology orientation (TO) has a significant impact on online SME performance & Accepted \\
H3: Learning capability (LC) has a significant impact on online SME performance & Accepted \\
\hline
\end{tabular}

learning capacity (LC), together explain 31.7 percent variance in determining the online SME performance in the study context. Table 3 also shows that EMO, TO and LC have been found as a significant determinant of online SME performance as all the proposed hypotheses are accepted at the 5\% significance level. Table 4 indicates the summary of the hypotheses test.

\section{DISCUSSION AND IMPLICATIONS}

This study is one of the studies that considered EMO, TO, and LC to determine their influence on online SME performance in a developing country such as Bangladesh where the operational activities of SME business organizations have been shifted to the Internet mediated online platform. The study has provided a significant contribution to the current literature by establishing the empirical relationship of EMO, TO, and LC with online SME performances, which are merely investigated, particularly in regard to developing nations, where SME businesses have been playing a critical part in fostering the national economic growth.

The present research effort has sought to measure the impact of e-marketing orientation (EMO), technology orientation (TO) and learning capacity (LC) on online SME performance in the context of Bangladesh. The study developed three hypotheses based on past studies in accordance with research objectives of the study, in which the proposed hypotheses were tested by applying regression analysis. The regression coefficient results reveal that the first hypothesis reports that e-marketing orientation (EMO) has a significant impact on online SME performance $(\mathrm{Hl})$, and the first hypothesis is accepted (H1: $\beta=0.260, p<0.05$ ). This does mean that online SME owners who exercise various electronic marketing activities will have an upward trend in their business performance on the online platform. This result supports the past research findings. E-marketing orientation does strongly affect the overall organizational performance of a non-profit based organization (Lee \& Ng, 2021). The second hypothesis of this study reports that technology orientation (TO) has a significant impact on online SME performance (H2), and the second hypothesis is accepted $(\mathrm{H} 2: \beta=0.279, p<0.05)$. This does indicate that if an online SME applies technology oriented activities in its business operations, then the firm performance tends to enhance over the period of time. Al-Henzab et al. (2018) found that technology orientation (TO) does contribute to the overall improvement of the firm performance in the pharmaceutical industry in Jordan. The third, and final, hypothesis reports that e-learning capacity (LC) has a significant impact on online SME performance (H3), and the third hypothesis is also supported (H3: $\beta=0.235, p<0.05)$. This finding aligns with past literature, which does imply that the acquisition of knowledge, through enhancing learning capacity at organizational level, has a direct influence on business performance (Jehangir et al., 2012).

This study presents several implications for online SME owners and entrepreneurs. Firstly, the study findings indicate that online SME managers and owners are required to adopt and integrate latest technological applications into business process to accelerate their business performance as online SMEs operate in a competitive environment. Because the acceptance and application of modern technologies by the business organizations will directly strengthen the overall business performance (Rajapathirana \& Hui, 2018). Secondly, to develop a competitive business strategy for SME on the online platform, marketing managers should focus on the adoption of various e-marketing platforms, such as email marketing, Facebook marketing, Youtube marketing, TikTok marketing, to develop better market positioning in the market. Lastly, the study finds that learning capacity is a predictor of business performance of online SMEs. Hence, business managers of SMEs should focus on enhancing internal learning capacity of relevant stakeholders by encouraging knowledge-generating activities among employees. 


\section{CONCLUSION}

This study has attempted to examine the influence of e-marketing orientation (EMO), technology orientation (TO) and learning capacity (LC) on online SME performance in the context of a developing country such as Bangladesh. Based on the results of correlation and regression analysis, the findings indicate that EMO, TO, and LC are strong and significant determinants of online SME performance. The study also finds that EMO, TO, and LC are strongly correlated with online SME performance at the 1 percent significance level. This does imply that a higher degree of e-marketing orientation, technology orientation, and learning capacity would result in higher online performance of small and medium-sized business organizations. Thus, SMEs are encouraged to focus on various e-marketing activities and the latest technologies to sustain and grow their online business operations. Also, SMEs should seek various learning sources to enhance their operational capabilities and improve their online performance in the competitive market.

\section{FUTURE RESEARCH DIRECTIONS}

The study offers several directions for future research with acknowledging some limitations. First, the study was quantitative in that it tested hypotheses using SPSS software. So, future researchers may consider applying qualitative research tools to find some new research findings that will enrich the body of the literature. The study measured the impact of three variables on online SME performance. Future research may consider some new variables such as employee skills, technological efficiency of SME managers/owners, and innovation orientation to determine online SME firm performance. The study collected data from Bangladeshi online SME firms. Future researchers may consider a cross-country sampling approach to produce more robust research results.

\section{AUTHOR CONTRIBUTIONS}

Conceptualization: Ahmed Al Asheq.

Data curation: Khadiza Rahman Tanchi, Md. Kamruzzaman, Md. Mobarak Karim.

Formal analysis: Ahmed Al Asheq, Khadiza Rahman Tanchi, Md. Mobarak Karim.

Funding acquisition: Khadiza Rahman Tanchi, Md. Kamruzzaman.

Investigation: Ahmed Al Asheq.

Methodology: Ahmed Al Asheq, Md. Mobarak Karim.

Project administration: Khadiza Rahman Tanchi, Md. Kamruzzaman, Md. Mobarak Karim.

Resources: Khadiza Rahman Tanchi, Md. Kamruzzaman, Md. Mobarak Karim.

Software: Ahmed Al Asheq, Md. Mobarak Karim.

Supervision: Khadiza Rahman Tanchi, Md. Kamruzzaman,, Md. Mobarak Karim.

Validation: Ahmed Al Asheq, Khadiza Rahman Tanchi.

Visualization: Khadiza Rahman Tanchi, Md. Kamruzzaman, Md. Mobarak Karim.

Writing - original draft: Ahmed Al Asheq, Khadiza Rahman Tanchi.

Writing - review \& editing: Ahmed Al Asheq, Md. Kamruzzaman, Md. Mobarak Karim.

\section{REFERENCES}

1. Ainin, S., Parveen, F., Moghavvemi, S., Jaafar, N. I., \& Mohd Shuib, N. L. (2015). Factors influencing the use of social media by SMEs and its performance outcomes. Industrial Management and Data Systems, 115(3), 570-588. https://doi. org/10.1108/IMDS-07-2014-0205
2. Alegre, J., \& Chiva, R. (2008). Assessing the impact of organizational learning capability on product innovation performance: An empirical test. Technovation, 28(6), 315-326. https://doi.org/10.1016/j.technovation.2007.09.003
3. Al-Henzab, J., Tarhini, A., \& Obeidat, B. Y. (2018). The associations among market orientation, technology orientation, entrepreneurial orientation and organizational performance. Benchmarking: An International Journal, 
25(8), 3117-3142. https://doi. org/10.1108/BIJ-02-2017-0024

4. Ambrosini, V., \& Bowman, C. (2009). What are dynamic capabilities and are they a useful construct in strategic management? International Journal of Management Reviews, 11(1), 29-49. https://doi. org/10.1111/ijmr.2009.11.issue-1

5. Ardito, L., \& Dangelico, R. M. (2018). Firm environmental performance under scrutiny: The role of strategic and organizational orientations. Corporate Social Responsibility and Environmental Management, 25(4), 426-440. https://doi.org/10.1002/csr.1470

6. Ariyachandra, T. R., \& Frolick, M. N. (2008). Critical success factors in business performance management - Striving for success. Information Systems Management, 25(2), 113-120. https://doi. org/10.1080/10580530801941504

7. Borges, M., Hoppen, N., \& Luce, F. B. (2009). Information technology impact on market orientation in e-business. Journal of Business Research, 62(9), 883890. https://doi.org/10.1016/j. jbusres.2008.10.010

8. Brodie, R. J., Winklhofer, H., Coviello, N. E., \& Johnston, W. J. (2007). Is e-marketing coming of age? An examination of the penetration of e-marketing and firm performance. Journal of Interactive Marketing, 21(1), 2-21. https://doi.org/10.1002/dir.20071

9. Buli, B. M. (2017). Entrepreneurial orientation, market orientation and performance of SMEs in the manufacturing industry: Evidence from Ethiopian enterprises. Management Research Review, 40(3), 292-309. https://doi. org/10.1108/MRR-07-2016-0173

10. Chatterjee, S., Gupta, S. D., \& Upadhyay, P. (2020). Technology adoption and entrepreneurial orientation for rural women: Evidence from India. Technological Forecasting and Social Change, 160, 120236. https://doi.org/10.1016/j. techfore.2020.120236

11. Chiva, R., Alegre, J., \& Lapiedra, R. (2007). Measuring organisational learning capability among the workforce. International Journal of Manpower, 28(3/4), 224-242. https://doi. org/10.1108/01437720710755227

12. Coviello, N. E., Milley, R., \& Marcolin. B. (2001). Understanding IT-enabled interactivity in contemporary marketing. Journal of Interactive Marketing, 15(4), 18-33. https:// doi.org/10.1002/dir.1020

13. Drennan, J., \& McColl-Kennedy, J. R. (2003). The relationship between internet use and perceived performance in retail and professional service firms. Journal of Services Marketing, 17(3), 295-311. https://doi. org/10.1108/08876040310474837

14. Durbin, J., \& Watson, G. S. (1950). Testing for serial correlation in least squares regression I. Biometrika, 37(3-4), 409-428. https://doi.org/10.2307/2332391

15. Eid, R., \& El-Gohary, H. (2013). The impact of E-marketing use on small business enterprises' marketing success. The Service Industries Journal, 33(1), 31-50. https://doi.org/10.1080/02642069. 2011.594878

16. Gao, G. Y., Zhou, K. Z., \& Bennett-Yim, C. K. (2007). On what should firms focus in transitional economies? A study of the contingent value of strategic orientations in China. International Journal of Research in Marketing, 24(1), 3-15. https://doi.org/10.1016/j.ijresmar.2006.09.004

17. García-Sánchez, E., GarcíaMorales, V. J., \& Martín-Rojas, R. (2018). Influence of technological assets on organizational performance through absorptive capacity, organizational innovation and internal labour flexibility. Sustainability, 10(3), 1-25. https://doi.org/10.3390/ su10030770

18. Hao, S., \& Song, M. (2016). Technology-driven strategy and firm performance: Are strategic capabilities missing links? Journal of Business Research, 69(2), 751759. https://doi.org/10.1016/j. jbusres.2015.07.043
19. Hernández-Linares, R., Kellermanns, F. W., \& López-Fernández, M. C. (2021). Dynamic capabilities and SME performance: The moderating effect of market orientation. Journal of Small Business Management, 59(1), 162-195. https://doi.org/10.1111/ jsbm.12474

20. Hooper, V., Huff, S., \& Thirkell, P. C. (2007). IS-marketing alignment: Its impacts on marketing performance and on business performance. Proceedings of the 15th European Conference on Information Systems (ECIS 2007). Retrieved from http://aisel. aisnet.org/ecis2007/101_

21. Idrus, S., Abdussakir, A., \& Djakfar, M. (2020). The effect of entrepreneurial orientation and technology orientation on market orientation with education as moderation variable. Management Science Letters, 10(10), 23512360. http://dx.doi.org/10.5267/j. msl.2020.2.030

22. Jehangir, M., Dominic, P. D D., Langove, N., \& Khan, A. (2012). Managerial expertise, top management support and learning capacity impact on e-commerce capability and business performance. International Journal of Business Innovation and Research, 6(4), 379-390. https://doi. org/10.1504/IJBIR.2012.047272

23. Keh, H., Nguyen, T., \& Ping, N. H. (2007). The effects of entrepreneurial orientation and marketing information on the performance of SMEs. Journal of Business Venturing, 22(4), 592-611. https://doi.org/10.1016/j.jbusvent.2006.05.003

24. Kocak, A., Carsrud, A., \& Oflazoglu, S. (2017). Market, entrepreneurial, and technology orientations: impact on innovation and firm performance. Management Decision, 55(2), 248270. https://doi.org/10.1108/MD04-2015-0146

25. Kutner, M. H., Kutner, M. H., Nachtsheim, C., \& Neter, J. (2004). Student solutions manual for use with applied linear regression models. New York, USA: McGrawHill/Irwin. 
26. Laukkanen, T., Nagy, G., Hirvonen, S., Reijonen, H., \& Pasanen, M. (2013). The effect of strategic orientations on business performance in SMEs. International Marketing Review, 30(6), 510-535. https://doi. org/10.1108/IMR-09-2011-0230

27. Lee, D. H., Dedahanov, A. T., \& Rhee, J. (2015). Moderating role of external networks and mediating effect of innovation performance on the relationship between technology orientation and firm performance. Asian Journal of Technology Innovation, 23(3), 321334. https://doi.org/10.1080/19761 597.2015.1120498

28. Lee, D., \& Ng, P. M. (2021). The role of organizational culture, capabilities, and adoption of e-marketing on non-profits' organizational performance. Journal of Philanthropy and Marketing, 26(2), 1-12. https://doi. org/10.1002/nvsm.1688

29. Mallén, F., Chiva, R., Alegre, J., \& Guinot, J. (2016). Organicity and performance in excellent HRM organizations: the importance of organizational learning capability. Review of Managerial Science, 10(3), 463-485. https://doi. org/10.1007/s11846-014-0164-2

30. Mandal, S. (2017). The influence of organizational culture on healthcare supply chain resilience: moderating role of technology orientation. Journal of Business \& Industrial Marketing, 32(8), 10211037. https://doi.org/10.1108/ JBIM-08-2016-0187

31. Mutlu, H. M., \& Sürer, A. (2016). Effects of market, e-marketing, and technology orientations on innovativeness and performance in Turkish health organizations. Health Marketing Quarterly, 33(2), 95-111. https://doi.org/10.1080/07 359683.2015.1093879

32. Raihan, S., Quoreshi, S., \& Rahim, A. (2016). Trade Winds of Change Women Entrepreneurs On The Rise In South Asia Background country study - Bangladesh. United Nations Development Programme (UNDP). Regional Bureau for Asia and the Pacific Bangkok Regional Hub. Retrieved from https://www.asia-pacific.undp.org/ content/rbap/en/home/library/ sustainable-development/tradewinds-of-change.html

33. Rajapathirana, R. J., \& Hui, Y. (2018). Relationship between innovation capability, innovation type, and firm performance. Journal of Innovation \& Knowledge, 3(1), 44-55. https://doi. org/10.1016/j.jik.2017.06.002

34. Real, J. C., Roldán, J. L., \& Leal, A. (2014). From entrepreneurial orientation and learning orientation to business performance: Analysing the mediating role of organizational learning and the moderating effects of organizational size. British Journal of Management, 25(2), 186-208. https://doi. org/10.1111/bjom.2014.25.issue-2

35. Saqib, M., Zarine, R., \& Udin, Z. M. (2018). Exploring the technology orientation influence on the innovativenessperformance relationship of manufacturing SMEs. International Journal of Innovation and Learning, 24(3), 277300. https://doi.org/10.1504/ IJIL.2018.094708

36. Shaltoni, A. M., \& West, D. C. (2010). The measurement of e-marketing orientation (EMO) in business-to-business markets. Industrial Marketing Management, 39(7), 1097-1102. https://doi.org/10.1016/j.indmarman.2009.06.011

37. Shaltoni, A. M., West, D., Alnawas, I., \& Shatnawi, T. (2018). Electronic marketing orientation in the Small and Medium-sized Enterprises context. European Business Review, 30(3), 272-284. https://doi.org/10.1108/EBR-022017-0034

38. Sheth, J. N., \& Sharma, A. (2005). International e-marketing: opportunities and issues. International Marketing Review 22(6), 611-622. https://doi. org/10.1108/02651330510630249

39. Siahaan, D. T., \& Tan, C. S. L. (2020). Antecedents of Innovation Capability and Firm Performance of Indonesian ICT SMEs. Asian Journal of Business Research, 10(2), 45-71. https://doi.org/10.14707/ ajbr.200083
40. Tsiotsou, R. H., \& Vlachopoulou, M. (2011). Understanding the effects of market orientation and e-marketing on service performance. Marketing Intelligence \& Planning, 29(2), 141-155. https://doi. org/10.1108/02634501111117593

41. Watson, R. P., Leyland, F. P., Berthon, P., \& Zinkham, G. (2002). U-commerce: expanding the universe of marketing. Journal of the Academy of Marketing Science, 30(4), 333-47. https://doi org/10.1177/2F009207002236909

42. Yousaf, S., Anser, M. K., Tariq, M., Jawad, S. U. R. S., Naushad, S., \& Yousaf, Z. (2020). Does technology orientation predict firm performance through firm innovativeness? World Journal of Entrepreneurship, Management and Sustainable Development, 17(1), 140151. https://doi.org/10.1108/ WJEMSD-11-2019-0091

43. Yousaf, Z. \& Majid, A. (2016). Strategic performance through inter-firm networks: strategic alignment and moderating role of environmental dynamism. World Journal of Entrepreneurship, Management and Sustainable Development, 12(4), 282298. https://doi.org/10.1108/ WJEMSD-03-2016-0015

44. Yousaf, Z., Sahar, N., Majid, A., \& Rafiq, A. (2018). The effects of e-marketing orientation on strategic business performance: Mediating role of e-trust. World Journal of Entrepreneurship, Management and Sustainable Development, 14(3), 309320. https://doi.org/10.1108/ WJEMSD-12-2017-0109

45. Zollo, M., \& Winter, S. G. (2002). Deliberate learning and the evolution of dynamic capabilities. Organization Science, 13(3), 339-351. https://10.1287/ orsc.13.3.339.2780 